\title{
Constipation in patients with myofascial pain syndrome as important aspect for clinical and nutritional treatment:
} A case-control study

\section{Constipação em pacientes com sindrome dolorosa \\ miofascial como importante aspecto para o \\ tratamento clínico e nutricional:}

um estudo caso-controle

João Araújo BARROS-NETO'

Tascya Morganna de Morais SANTOS²

Matheus Lopes CORTES 3

Rosangela Passos de JESUS ${ }^{4}$

Mariana Carvalho FREITAS 5

Durval Campos KRAYCHETE ${ }^{6}$

\section{A B S T R A C T}

\section{Objective}

To identify the occurrence of constipation in patients with myofascial pain syndrome and to correlate these disorders with the clinical and nutritional variables.

\section{Methods}

This report describes a case-control study performed with 98 adults of both sexs, including 49 patients and 49 individuals without pain. The intensity of the reported pain was evaluated using the Pain Visual Analog Scale, which provided a simple and efficient measurement of pain intensity consisting of a $10 \mathrm{~cm}$ horizontal line with

\footnotetext{
1 Universidade Federal de Alagoas, Faculdade de Nutrição, Curso de Nutrição. Av. Lourival Melo Mota, s/n., Cidade Universitária, 57072-900, Maceió, AL, Brasil. Correspondência para/Correspondence to: JA BARROS NETO. E-mails: <joaoaraujo.neto@hotmail.com>; <joao.neto@fanut.ufal.br>.

2 Instituto Federal de Alagoas, Departamento de Apoio Acadêmico, Área de Alimentos. Maceió, AL, Brasil.

3 Universidade Federal da Bahia, Instituto Muldisciplinar em Saúde, Curso de Nutrição. Vitória da Conquista, BA, Brasil.

${ }^{4}$ Universidade Federal da Bahia, Escola de Nutrição, Curso de Nutrição. Salvador, BA, Brasil.

${ }^{5}$ Centro Universitário Estácio do Ceará, Faculdades Integradas do Ceará, Departamento de Nutrição. Fortaleza, CE, Brasil.

${ }^{6}$ Universidade Federal da Bahia, Faculdade de Medicina, Departamento de Anestesiologia. Salvador, BA, Bahia.
} 
the ends marked "absence of pain" and "worst possible pain". The occurrence of constipation was evaluated using the Rome III criteria. A multivariate linear regression was proposed to investigate risk factors between the frequency of bowel movements per week and independent variables this study.

\section{Results}

The mean ages of the patients and controls were 45.9 (7.6) years and 41.2 (12.2) years, respectively. The intensity of the reported pain showed a mean of $7.3(1.6)$ points. The likelihood of exhibiting constipation was 4.5 times higher in the patients than in the controls $(p=0.001)$. The number of stools per week was negatively correlated with the intensity of the reported pain $(r=-0.613, p<0.001)$. The use of benzodiazepines was negatively correlated with the frequency of bowel movements per week, while the use of muscle relaxants appeared to increase the frequency of defecation when combined with the use of benzodiazepines and adjusted for the intake of fiber, water and sexs $(p=0.037)$.

\section{Conclusion}

Constipation was a frequent nosological entity in this patient population and the persistence of a change in intestinal motility showed a significant correlation with the pain intensity and low water intake. The reduction of the number of stools per week seems to be associated with the use of benzodiazepines.

Keywords: Chronic pain. Constipation. Myofascial pain syndromes.

\section{RE S U M O}

\section{Objetivo}

Identificar a ocorrência de constipação em pacientes com síndrome dolorosa miofascial e correlacionar essa desordem da motilidade intestinal com variáveis clínicas e nutricionais.

\section{Métodos}

Trata-se de um estudo de caso-controle, realizado com 98 indivíduos adultos de ambos os sexos, sendo 49 pacientes e 49 indivíduos sem dor. A intensidade da dor foi avaliada usando a Escala Visual Analógica de Dor, que forneceu uma medida simples e eficaz de intensidade da dor, e consiste em uma linha horizontal de $10 \mathrm{~cm}$ com as extremidades marcadas "ausência de dor" e "pior dor possivel". A ocorrência de constipação foi avaliada utilizando os critérios de Roma III. Uma regressão linear multivariada foi proposta para investigar fatores de risco entre a frequência de dejeções por semana e demais variáveis independentes do estudo.

\section{Resultados}

A média da idade dos pacientes e controles foi de 45,9 anos \pm 7,6 DP e 41,2 anos $\pm 12,2 D P$, respectivamente. A intensidade da dor referida mostrou uma média de 7,3 pontos \pm 1,6 DP. A probabilidade de exibir a constipação foi 4,5 vezes maior nos pacientes com dor miofascial que nos indivíduos do grupo controle $(p=0,001)$. A frequência de dejeções semanais relatada pelos pacientes apresentou correlação negativa com a intensidade da dor $(r=-0,613, p<0,001)$. O uso de benzodiazepínicos foi negativamente correlacionado com a frequência de dejeções por semana, enquanto que o uso de relaxantes musculares aumentou a frequência de dejeções quando combinado com o uso de benzodiazepínicos, e ajustado pela ingestão de fibras, água e sexo ( $p=0.037$ ).

\section{Conclusão}

A constipação foi uma entidade nosológica frequente no grupo de pacientes com dor miofascial. A alteração na motilidade intestinal mostrou uma correlação significativa com a intensidade da dor e a baixa ingestão hídrica. A redução do número de dejeções por semana parece estar associada ao uso de benzodiazepínicos.

Palavras-chave: Dor crônica. Constipação intestinal. Síndromes da dor miofascial.

\section{NTRODUCTION}

Chronic pain is considered a serious and growing public health problem worldwide. Affected people require medical attention approximately five times more frequently than the rest of the population. These patients have impaired physical, mental and social wellbeing, resulting in disability and work absenteeism [1,2].

Myofascial Pain Syndrome (MPS) is characterized by regional chronic muscle pain located in a single muscle or in muscle groups. 
MPS is an incapacitating muscle process that is highly prevalent worldwide; however, this condition is rather unknown and thus, is underdiagnosed, most likely because detectable structural changes are not always observed, and the condition is commonly associated with other musculoskeletal processes. Furthermore, several muscle injuries meet the diagnostic criteria for MPS [2,3]. A physical examination reveals the occurrence of a taut band with Myofascial Trigger Points (MTrPs) in its center that correspond to an area of hypersensitivity and increased firmness. Palpation of this area reproduces both the local and distant pain [2-4].

The diagnostic methods used for MPS are controversial. Some researchers suggest that the focal areas of muscle pain defined as associated with MTrPs may not be reliably identified [5-7]. At present, the criteria established by Simons and Travell's study seem to be the most accepted diagnostic method worldwide. These criteria increase the percentage of agreement between different researchers by considering the existence of MTrPs during muscle palpation with a typical pattern of referred pain as a manifestation of local response contractions or muscle contractions and the restricted joint mobility of the compromised muscles $[3,4,8]$.

Few population-based studies worldwide have reported the prevalence and factors related to MPS. It is estimated that approximately $30 \%$ of cases of pain reported in medical clinics and $93 \%$ of cases in specialized centers are related to MPS in the United States population [8-10].

Irritable Bowel Syndrome (IBS), especially the constipation-predominant subtype (IBS-C), has also been frequently reported in patients with chronic musculoskeletal pain $[11,12]$. Estimates of the prevalence of constipation in Brazil are unclear; however, this nosological entity has been linked to a reduced quality of life and the occurrence of psychosocial disorders [13].

Studies conducted in IBS patients showed that patients with constipation more commonly reported musculoskeletal pain as one of the chronic extra-intestinal symptoms than patients with diarrhea $[14,15]$.

Although the relationships have not yet been clarified, some hypotheses try to explain the possible relationship between centrally mediated pain processes and the presence of visceral inflammation, which is commonly observed in the colons of individuals with IBS-C. Animal model studies suggest that crosssensitization where inflammation and visceral pain are centrally transmitted for processing via the spinothalamic may provide an explanation [16-19].

Another possible hypothesis is the release and activation of Nuclear Factor Kappa (NF-кB), which is commonly observed in the reduction of intestinal motility. NF- $\kappa \mathrm{B}$ activates the expression of genes, resulting in the synthesis and release of pro-inflammatory cytokines that increase the sensitivity of nociceptors to painful stimuli and may lead to pain or enhance the pain response $[20,21]$. However, the mechanisms by which the occurrence of pain correlates with constipation are poorly understood.

Regardless of underlying causes and consequences of pain, inflammation is the main warning sign of the organism in response to tissue injury $[22,23]$, which may intensify the painful nociception and reduce the quality of life of these individuals. Thus, a diet with specific foods, rich in micronutrients, lipids (rich in Monounsaturated Fatty Acids [MUFA]), antioxidants and fiber, possibly associated with dietary supplements, can provide helpful support for patients suffering with chronic pain and help in treating related problems such as constipation [24].

Because constipation is commonly found in patients with chronic musculoskeletal pain, the current study aimed to identify the occurrence of this intestinal motility disorder in patients with myofascial pain syndrome and to correlate the occurrence of this syndrome with 
the clinical and nutritional variables reported by this population.

\section{METHODS}

This is a case-control study conducted with 98 subjects with myofascial pain syndrome who were treated at the outpatient pain clinic of the Universidade Federal da Bahia from April to October of 2014, of both sexs who were older than 19 years and younger than 65 years of age. Group 1 was formed with 49 patients who were previously diagnosed with MPS and met none of the exclusion criteria; this group was compared to a group of 49 individuals with no diagnosis of chronic pain (Group 2) who consisted of relatives of patients who resided in the same household or in its proximity and had similar socioeconomic conditions. Both groups were matched by sexs, age, income and education (Figure 1). For this case-control study, the sample size calculation was performed considering the proportion of 1 control for each case and considering the average proportion of exposed cases between approximately $50 \%$ and approximately $20 \%$ of those exposed Controls, totalizing a number of 49 patients and 49 controls in the final sample.

The diagnosis of myofascial pain syndrome in any muscle was realized by specialized doctors after performing a thorough physical examination to identify the occurrence of MTrPs in one or more of the following muscles: the trapezius, infraspinatus, gluteus maximus, quadratus lumborum, and/or levator scapulae (cervical portion). The occurrence of MTrPs was diagnosed based on neck or shoulder pain that may or may not have been accompanied by the typical pattern of referred pain in the compromised muscle. After performing a thorough physical examination, MPS was diagnosed using the Simons Criteria, which required five major and at least one of the four minor criteria to be satisfied (Major criteria: (1) localized spontaneous pain; (2) spontaneous pain or altered sensations in the expected referred pain area for the given MTrP; (3) taut, palpable band in the accessible muscle; (4) exquisite, localized tenderness in a precise point along the taut band; and (5) some measurably reduced movement range. Minor criteria: (1) reproduction of spontaneously perceived pain and altered sensations by pressure on an MTrP; (2) elicitation of a local twitch response of the muscular fibers by transverse 'snapping' palpation or by needle insertion into the MTrP; (3) pain relief obtained by muscle stretching or dry needling injection of the MTrP; and (4) electromyographic demonstration of spontaneous electrical activity characteristic of active loci in the tender nodule of a taut band in the muscle) [3]. The pain Visual Analog Scale (VAS) was used to assess the pain intensity. Patients reporting a moderate pain intensity $(\geq 4$ points) were included in the study.

Following admission to the study, in both groups, a triage was performed to exclude patients with radiculopathy, degenerative or inflammatory joint disorders, central or peripheral neuropathies, nerve compression syndromes, multiple sclerosis, myasthenia gravis and polymyositis, non-rheumatic diseases, including hypothyroidism, metabolic (myophosphorylase deficiency, cytolysin abnormalities and phosphofructokinase deficiency), or infectious disorders (herpes virus, picornavirus, Trichinella spiralis, cysticercosis and toxoplasmosis, hepatitis B or C, human T-lymphotropic virus or human immunodeficiency virus), chronic fatigue syndrome and fibromyalgia.

The treatment protocol was applied to collect data on the socio-demographics, lifestyle, dietary habits, nutritional statuses and Rome III criteria for the evaluation of the intestinal motility and clinical characteristics of pain, including the duration and intensity. The pain intensity was evaluated using the VAS, which provides a simple and efficient measurement of the pain intensity and consists of a $10 \mathrm{~cm}$ horizontal line that measures the pain intensity reported by 


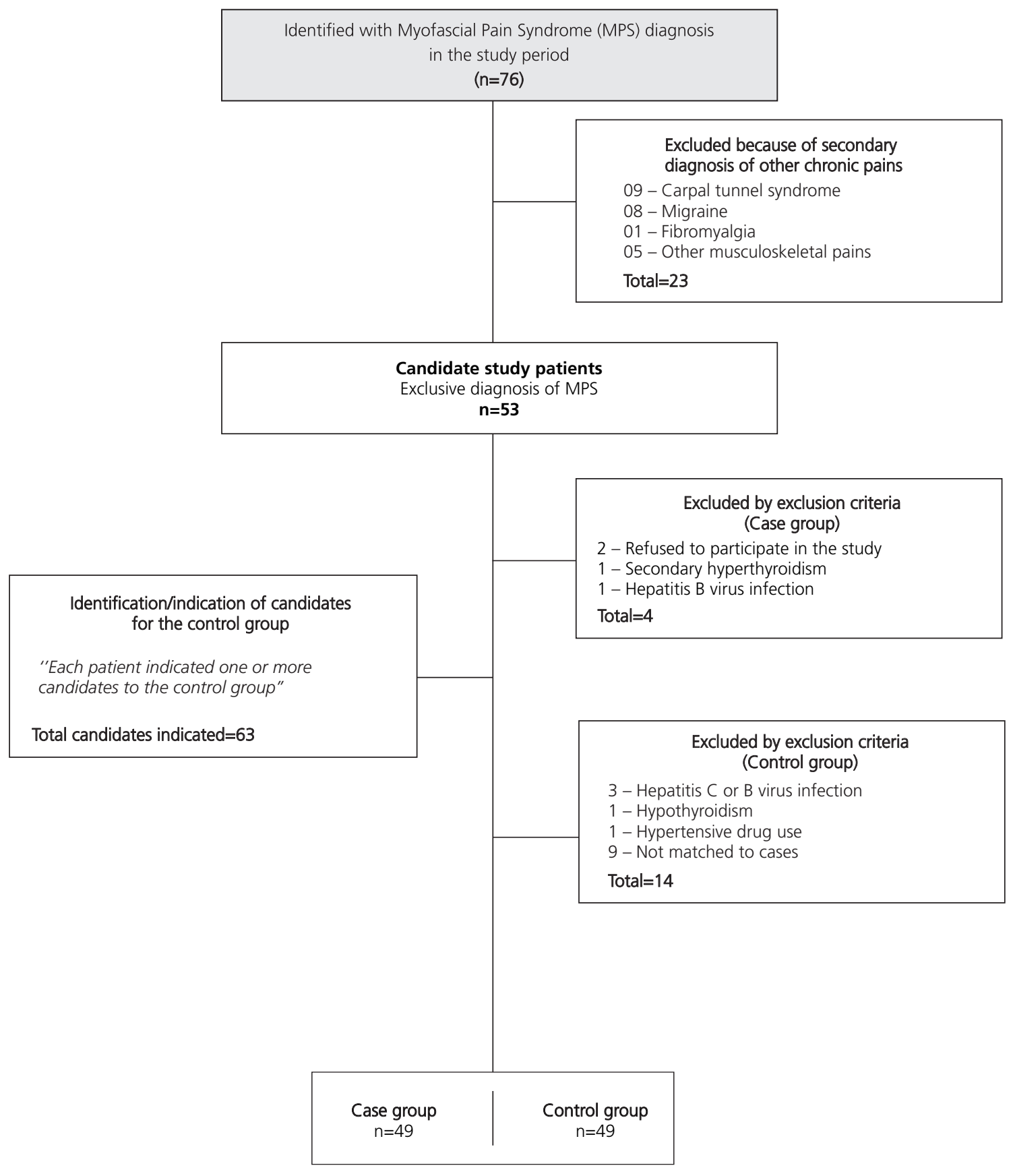

Figure 1. Recruitment stages of the research study. Salvador (BA), 2014.

the patient at that moment. The pain intensity corresponds to an integer scale ranging from 0 to 10 , where zero is an absence of pain and 10 is the worst pain possible [25]. The cutoff points established were as follows: 0 , absence of pain; 1 - 3.9, mild pain; 4 - 7.9, moderate pain; and $>8$, intense pain.
A lifestyle evaluation was performed by assessing alcohol consumption, smoking habits, and reported physical activity practices. We considered alcohol users to be patients who consumed alcohol regardless of the frequency (even $<1$ drinks/month), non-consumers to be patients who reported never drinking and former 
consumers to be patients who mentioned that they had ceased drinking alcohol for at least one month [26]. With respect to smoking, participants who had not smoked 100 cigarettes were defined as never having smoked. Those who provided affirmative responses to both questions were considered to be current smokers. Participants who had smoked 100 cigarettes but did not report smoking at the time of the survey were considered as former smokers [26].

Individuals who reported practicing moderate-intensity aerobic exercise at least 30 minutes/day 5 days a week or strenuous activities for at least 20 minutes/day 3 times a week were considered physically active following the criteria of the American College of Sports Medicine and the American Heart Association [27].

All food and beverages consumed were recorded in 24-hour dietary recall interview for two days during different medical appointments. To assess the fiber intake, the calculated values in the food surveyswere adjusted and corrected for the variability of consumption among individuals in the same group using the methodology described in the Dietary Reference Intakes [28]. The Recommended Dietary Intake (RDI) correlating fiber consumption with the caloric intake was used as a parameter of the ideal fiber intake, which advocated the consumption of $14 \mathrm{~g}$ of fiber per $1000 \mathrm{kcal}$ ingested for chronic disease prevention and the maintenance of healthy intestinal motility [28].

The nutrition support program Avanutri ${ }^{\circledR}$ version 3.09 (2008; Avanutri Informática Ltda, Três Rios, Rio de Janeiro, Brazil) complemented the food composition table of the Estudo Nacional de Despesa Familiar (ENDEF, National Study of Household Expenditure), which was used to calculate the fiber content for regional foods [29]. The assessment of the mean fiber intake and water intake was performed using the mean of the food consumption recorded in the 24-hour recall questionnaires applied on two random days.
Water intake was also assessed according to the RDI, which advocated adequate intake values for sedentary individuals of $3.7 \mathrm{~L}$ day for men and 2.7L/day for women. Higher values were recommended for physically active individuals [30].

Weight, height and Body Mass Index (BMI) were assessed among the anthropometric variables. A digital scale with a $200 \mathrm{~kg}$ capacity and a $50 \mathrm{~g}$ accuracy was used to assess the weight. The weighing procedure was performed according to the standardization by Lohman et al. [31]. Height was assessed using a portable stadiometer that was graduated in tenths of centimeters and affixed to a flat surface. The procedures for measuring height followed the standardization proposed by Lohman [32]. The $\mathrm{BMI}$ was assessed through the ratio of weight $(\mathrm{kg})$ to squared height $(\mathrm{m})$ using the cutoff points of the World Health Organization for normal weight $\left(18.5-24.9 \mathrm{~kg} / \mathrm{m}^{2}\right)$ and considering values equal to or higher than $25 \mathrm{~kg} / \mathrm{m}^{2}$ as overweight [33].

The Rome III criteria were applied to evaluate the occurrence of decreased intestinal motility. Intestinal constipation was defined as the presence of the following criteria: straining upon defecation; hard or lumpy stools; sensation of incomplete defecation; sensation of anorectal obstruction or blockage; manual maneuvers to facilitate defecation; and fewer than three bowel movements per week. The subjects were instructed to answer the questions on spontaneous bowel function (i.e., without the use of laxatives, teas or any other type of therapeutic strategy). The occurrence of two or more such criteria in the last six months typified the occurrence of intestinal constipation. Each criterion was considered positive when it reached the following cutoff points: (1) straining upon defecation in at least $25 \%$ of defecations - response equivalent to "frequently" (question A $\geq 2$ ); (2) hard or lumpy stools in at least $25 \%$ of defecations - response equivalent to "frequently" (question $B \geq 2$ ); (3) 
sensation of incomplete defecation in at least $25 \%$ of defecations - response equivalent to "sometimes" (question $C \geq 1$ ); (4) sensation of anorectal obstruction/blockage in at least 25\% of defecations - reply equivalent to "sometimes" (question $D \geq 1$ ); 5) manual maneuvers to facilitate at least $25 \%$ of defecations - response equivalent to "sometimes" (question $\mathrm{E} \geq 1$ ); and (6) less than three defecations per week [34].

A descriptive statistical analysis was used to characterize the distribution of the events studied by assessing simple absolute frequencies for categorical variables and measures of mean or median and Standard Deviation or Interquartile Range for continuous variables - M (SD/IQ). The behavior of the variables was assessed prior to proceeding with the analysis using the ShapiroWilk test. Proportions were compared using the Chi-square test or Fisher's exact test, with any descriptive level ( $p$-value) below 5\% considered statistically significant. The magnitude of the association between $X$ and $Y$ was assessed by the odds ratio. Student's $t$-test and the nonparametric Mann-Whitney $U$ test were used to compare the means between groups by adopting a significance level of $p<0.05$. Correlation analyses between continuous variables were performed using Pearson's correlation test. A multivariate regression was proposed to investigate risk factors between the frequency of bowel movements per week and the use of drugs, water intake, dietary fiber intake, sexs and other independent variables. The Statistical Package for Social Science (SPSS, Inc., Chicago, Illinois, United States) software version 17.0 was used for data processing.

The Ethics and Research Committee of the School of Nutrition, Universidade Federal da Bahia (UFBA), approved the aforementioned study (Case $n^{\circ}$ 0308/2014). Eligible patients signed an informed consent form in accordance with Resolution $n^{\circ} 466 / 12$ governing clinical research with human subjects to participate in the study. All data from the studied patients were kept confidential, and all patients had the right to withdraw from participation in this research Protocol at any stage.

\section{RE S U L T S}

Table 1 shows the characterization of the sample population. The statistical analysis showed no differences in age or anthropometric variables with the exception of height, which exhibited the lowest values in group 1 .

The duration of pain was on average 7.2 (5.4) years in group 1. The reported pain intensity showed a minimum value of 4 and a maximum of 10 points, with a mean of 7.3 (1.6).

The participants' fiber intakes showed no significant differences between groups ( $p=0.538$ ), and $79.6 \%$ of group 1 subjects and $87.7 \%$ of group 2 subjects showed a low water intake $(p=0.274)$. The mean water intake among the men and women from group 1 was 2.380(485.5) $\mathrm{mL}$ day and 2.256 (644.1) $\mathrm{mL} /$ day $S D$, respectively, whereas for group 2 , the means were 2.795 (337.0) mL/day and 2.287 (647.4) $\mathrm{mL} /$ day in men and women, respectively (Table 1).

The groups showed a significant difference regarding physical activity. Group 1 was sedentary, whereas group 2 reported exercising (Table 1).

Regarding the evaluation of intestinal motility, none of the subjects from either group exhibited a pattern of diarrhea. The frequency of constipation was proportionally higher in the group of patients with MPS, and the probability of exhibiting constipation was 4.5 times higher than in individuals without pain $(p=0.001)$.

The number of stools per week was negatively correlated with the intensity of the pain reported by the patients with MPS (i.e., a lower the frequency of bowel movements per week was correlated with a higher pain intensity reported by the patients) $(r=-0.613 ; p<0.001)$ and was positively correlated with water intake/day ( $r=0.444 ; p=0.12)$, but showed no correlation with fiber intake $(r=-0.200 ; p=0.288)$ in either group (Table 2).

There was no statistical correlation between the use of one isolated drug and the 
Table 1. Characterization of sociodemographic, lifestyle, anthropometric variables, fiber and water intake. Salvador (BA), 2014.

\begin{tabular}{|c|c|c|c|c|c|c|}
\hline \multirow{2}{*}{ Variables } & \multicolumn{2}{|c|}{ Group 1} & \multicolumn{2}{|c|}{ Group 2} & \multirow{2}{*}{ Crude OR } & \multirow{2}{*}{$p$} \\
\hline & $\mathrm{N}$ & $\%$ & $n$ & $\%$ & & \\
\hline \multicolumn{7}{|l|}{ Sexs } \\
\hline Male & 14 & 28.6 & 15 & 30.6 & & \multirow{2}{*}{$0.825^{\mathrm{a}}$} \\
\hline Female & 35 & 71.4 & 34 & 69.4 & - & \\
\hline \multicolumn{7}{|l|}{ Smoking } \\
\hline Yes & 3 & 6.1 & 1 & 2.0 & \multirow{2}{*}{-} & \multirow{2}{*}{$0.617^{b}$} \\
\hline No & 46 & 93.9 & 48 & 98.0 & & \\
\hline \multicolumn{7}{|l|}{ Alcohol use } \\
\hline Yes & 8 & 16.3 & 22 & 44.9 & \multirow{2}{*}{0.24} & \multirow{2}{*}{$0.002^{a}$} \\
\hline No & 41 & 83.7 & 27 & 55.1 & & \\
\hline \multicolumn{7}{|l|}{ Physical Exercise } \\
\hline Yes & 18 & 36.7 & 29 & 59.2 & \multirow{2}{*}{2.50} & \multirow{2}{*}{$0.026^{a}$} \\
\hline No & 31 & 63.3 & 20 & 40.8 & & \\
\hline \multicolumn{7}{|l|}{ Constipation } \\
\hline Yes & 23 & 46.9 & 8 & 16.3 & \multirow{2}{*}{4.53} & \multirow{2}{*}{$0.001^{\mathrm{a}}$} \\
\hline No & 26 & 53.1 & 41 & 83.7 & & \\
\hline \multicolumn{7}{|l|}{ Low fiber intake } \\
\hline Yes & 5 & 10.2 & 7 & 14.3 & \multirow{2}{*}{-} & \multirow{2}{*}{$0.538^{b}$} \\
\hline No & 44 & 89.8 & 42 & 85.7 & & \\
\hline \multicolumn{7}{|l|}{ Low water intake } \\
\hline Yes & 10 & 20.4 & 6 & 12.3 & \multirow{2}{*}{ - } & \multirow{2}{*}{$0.274^{\mathrm{a}}$} \\
\hline \multirow[t]{2}{*}{ No } & 39 & 79.6 & 43 & 87.7 & & \\
\hline & Mean/Median & $\mathrm{SD} / \mathrm{IQ}$ & Mean/Median & $\mathrm{SD} / \mathrm{IQ}$ & $95 \% \mathrm{Cl}$ & $p$ \\
\hline Age (years) & 45.90 & 8.60 & 41.20 & 12.00 & - & $0.093^{c}$ \\
\hline $\mathrm{BMI}\left(\mathrm{kg} / \mathrm{m}^{2}\right)$ & 27.30 & 3.90 & 25.50 & 5.50 & $-0.22-3.25$ & $0.184^{d}$ \\
\hline Fiber intake (g/1000kcal) & 7.21 & 2.79 & 7.87 & 2.74 & $2.09-0.78$ & $0.459^{d}$ \\
\hline \multicolumn{7}{|l|}{ Water intake } \\
\hline Men & 2380.00 & 485.51 & 2795.00 & 337.02 & $-1242.44-26.73$ & $0.058^{d}$ \\
\hline Women & 2256.00 & 644.12 & 2287.00 & 647.43 & $-466.25-334.11$ & $0.741^{\mathrm{d}}$ \\
\hline Total & 2318.00 & 637.56 & 2536.00 & 642.33 & $-589.66-60.33$ & $0.109^{d}$ \\
\hline
\end{tabular}

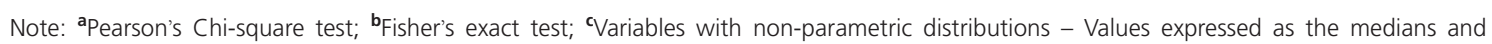
interquartile range (Mann-Whitney test); ${ }^{d}$ Variables with parametric distributions - Values expressed as the means and standard deviation ( $t$-test); 95\% Cl: 95\% Confidence Interval; SD: Standard Deviation; IQ: Interquartile Range; BMI: Body Mass Index; OR: Odds Ratio.

Table 2. Correlation between number of stools per week with the pain intensity, water and fiber intake. Salvador (BA), 2014.

\begin{tabular}{lll}
\hline \multirow{2}{*}{ Variables } & \multicolumn{2}{c}{ Number of stools per week } \\
\cline { 2 - 3 } Pain intensity & Group 1 & Group 2 \\
& $r=-0.613$ & - \\
Water intake & $p<0.001$ & $r=-0.040$ \\
& $r=0.444$ & $p=0.832$ \\
Fiber intake & $p=0.012$ & $r=-0.096$ \\
& $r=-0.200$ & $p=0.615$ \\
\hline
\end{tabular}


Table 3. Multivariate linear regression of the number of stools per week in patients with myofascial pain syndrome. Salvador (BA), 2014.

\begin{tabular}{|c|c|c|c|c|c|c|}
\hline \multirow{2}{*}{ Variables } & \multicolumn{2}{|c|}{ Model $1(n=49)$} & \multicolumn{2}{|c|}{ Model $2(n=49)$} & \multicolumn{2}{|c|}{ Model $3(n=49)$} \\
\hline & B & $p$ & $\beta$ & $p$ & $\beta$ & $p$ \\
\hline Benzodiazepines & -0.482 & 0.003 & -0.424 & 0.031 & - & - \\
\hline Muscle relaxant & 0.402 & 0.004 & - & - & 0.374 & 0.112 \\
\hline Intensity of pain & -1.563 & $<0.001$ & -1.589 & $<0.001$ & -1.525 & $<0.001$ \\
\hline Fiber intake (g/day) & -0.051 & 0.610 & -0.061 & 0.536 & -0.033 & 0.547 \\
\hline Sexs & -0.265 & 0.068 & -0.402 & $<0.001$ & -0.402 & 0.016 \\
\hline Water intake (L/day) & 0.003 & $<0.001$ & 0.003 & $<0.001$ & 0.502 & 0.001 \\
\hline$R^{2}$ & \multicolumn{2}{|c|}{0.562} & \multicolumn{2}{|c|}{0.552} & \multicolumn{2}{|c|}{0.484} \\
\hline$R^{2}$ adjusted & \multicolumn{2}{|c|}{0.466} & \multicolumn{2}{|c|}{0.458} & \multicolumn{2}{|c|}{0.396} \\
\hline
\end{tabular}

occurrence of constipation in the group of MPS patients ( $p>0.05$ ). However, a multivariate regression model adjusted for water, fiber intake, and sexs was performed to explain the effect of the use of medication and pain intensity on the reduction of the number of bowel movements per week (Table 3). The use of opioids showed no significant association with constipation in this study. The use of benzodiazepines and pain intensity were negatively correlated with the frequency of bowel movements per week in all observed models. The use of muscle relaxants (cyclobenzaprine or baclofen) appeared to increase the frequency of defecation when combined with the use of benzodiazepines and adjusted for the intake of fiber, water and sexs $(p=0.037)$.

\section{I S C U S S I O N}

The current study evaluated the frequency of constipation in patients with myofascial pain syndrome and compared these patients' clinical characteristics and intestinal motility patterns with subjects without a previous MPS diagnosis. The statistical power of the sample was calculated to assess the correlation between chronic pain and constipation. The result of this analysis indicated that the sample had a power of $90 \%$ with $95 \%$ confidence.
No other study was found in the literature that assessed constipation in patients with MPS, and few studies with this purpose have been performed in patients with fibromyalgia, which is a musculoskeletal pain subtype; the former (myofascial) serves as a paradigm of localized pain, and the latter (fibromyalgia) serves as a representative of diffuse pain.

In the current study, a higher number of patients did not perform any type of physical exercise compared to group 2 . The practice of physical activity appears to play an important role in the modulation of painful nociception. A study evaluating the prevalence of risk factors linked to painful symptoms considered sedentary lifestyle as a key risk factor for the onset of musculoskeletal pain, which corroborated the previous findings [35].

A systematic review found that the practice of physical exercise could affect the reduction of musculoskeletal pain. This correlation may be partially explained by the activation of muscle tension receptors during strong muscle contractions, the afferents of which trigger the release of endogenous opioids that stimulate the release of endorphins by the pituitary gland, thereby reducing central and peripheral pain nociception [36]. Other authors relate the practice of physical exercise to growth of blood capillaries, which favor the oxygen 
supply, removal of algogenic metabolic wastes and pain reduction [37]. However, we must note that these beneficial effects directly depend on the nature of the training program, the ongoing monitoring by a specialized professional and, in particular, the pain intensity.

In another study, there was a high prevalence of intestinal constipation in MPS patients, which was consistent with the data found in the literature that reported a frequency of constipation that ranged from $42 \%$ to $63 \%$ in patients with chronic musculoskeletal pain $[11,38]$. Results similar to those found in this sample were also found in a study conducted by Helfestein Jr. et al. [11], that involved patients with fibromyalgia-type musculoskeletal pain, wherein the most frequent IBS subtype was constipation-predominant, resulting in a $60.5 \%$ prevalence of constipation among all patients in the study. Several research studies involving patients with musculoskeletal pain have examined the correlation between these two nosological entities, although more focus has been given to the central nervous system structures involved in pain perception and colonic stimulation [39]. There is no scientific evidence to explain the frequent occurrence of this nosological entity in patients with myofascial pain, although several studies have indicated the occurrence of constipation in patients with musculoskeletal pain $[11,40,41]$. However, to establish constipation in our study we employed a method subjective evaluation tool (Roma III), but internationally validated and recognized for considering the effort to defecate, frequency and consistency (shape) of feces, classified by Bristol Fecal Shape Scale (EBFF) [34].

One possible explanation for the common coexistence of both clinical conditions is related to the release of serotonin by enterochromaffin cells of the gastrointestinal tract. Enterochromaffin cells activate several subtypes of receptors located in the submucosa and the myenteric neurons of the enteric nervous system, thereby performing a key role in the normal function of the gastrointestinal tract $[42,43]$, this is changes in serotonin metabolism are plausible, especially deficiencies in synthesis and turnover, which may occur in patients with musculoskeletal pain and contribute to a reduction in intestinal motility and consequent constipation.

Another hypothesis capable of explaining the relationship between constipation and MPS may be related to the "convergenceprojection" theory of the referred visceral sensitivity that assumes input from both somatic and visceral structures onto the same second order spinal neuron [44]. This theory has been well documented clinically and extensively researched in visceral disease studies, where it is termed "cross-organ sensitization" $[18,45]$.

Studies using animal models suggest that cross-sensitization among pelvic viscera may result in referred chronic pain $[16,18]$. The main mechanism explaining cross-organ sensitization is based on so-called dichotomizing fibers (i.e., sensory endings of a single neuron innervating two different tissues) [44] that can to innervate the colon and to initiate the expression of peripheral transient potential vanilloid 1 receptors enhancing N-Methyl-D-aspartate) phosphorylation in the presence of inflammation; both of these factors are involved in nociceptive mechanisms of chronic musculoskeletal pain [46-48]. Thus, an inflammatory process initiated in any organ (e.g., colitis present in cases of chronic constipation) may trigger cross-organ sensitization and the onset of pathological conditions of centrally mediated chronic pain or enhance preexisting pain $[44,49,50]$.

Therefore, its possible to believe that the occurrence of constipated bowel movements in MPS patients may also have favored the increased pain intensity in this group, as this correlation between the frequency of stools per week and the pain intensity was observed in the current study. Additionally, significant increases in the plasma levels of proinflammatory cytokines (TNF- $\alpha, \quad \mathrm{LL}-1 \beta, \quad \mathrm{L}-6$ and $\mathrm{IL}-8$ ) are found in patients with intestinal disorders 
favoring mucosal inflammation, including constipation-predominant IBS [51,52]. This correlation can be explained by the sustained stimulation of nociceptors in chronic pain by proinflammatory cytokines pathway, resulting in local hypersensitivity, hypersensitivity in the adjacent regions and increased Central Nervous System responsiveness through chemical, physical or mechanical stimuli $[53,54]$.

Despite the high frequency of constipation in MPS patients and the effect that a low fiber intake has on the reduction of intestinal peristalsis with consequent constipation, this correlation was not observed in this study, most people inserted in group 1 or 2 independently showed low intake of dietary fiber, corroborating the Dietary Guidelines for Americans that classified the dietary fiber as a nutrient of concern because more than $90 \%$ of the population failed to find their daily dietary fiber recommendations [55].

Errors inherent to the method of evaluating food consumption may explain why there was no differences in fiber intake between the groups, which influence the standardization of portions and household measures during the evaluation, the memory of the respondents, the sample size and the heterogeneity of dietary patterns, making it impossible to evaluate food consumption without errors [56]. Therefore, nutrient intake evaluations should be interpreted with caution in patients with clinical signs of constipation, since in addition to the fragility of the consumption evaluation methods, the presence of the disease may also reflect changes in the food choices.

The positive relation between intake of dietetic fiber and water on human health and intestinal transit is already well known $[57,58]$. In patient group with MPS the water consumption showed a negative relation with the number of stools per week, favoring the hypothesis that increased water intake may aid in the treatment and prevention of constipation, since inadequate water consumption is a common cause of constipation [59]. However, there is evidence that low fiber and water intake is not always a causal factor for constipation, and other factors need to be investigated [57-60].

In this study, could be established in the multivariate regression models a relationship between the reduction in the number of defecations per week in this group and the low water intake and use of benzodiazepines and muscle relaxants and pain intensity could be established in the multivariate regression models.

Increased pain intensity favors the excessive use of medications for analgesia. The high frequency of constipation observed among MPS patients may also be the result of side effects of psychotropic drugs [61], excessive use of opioids (not significant in this study), a sedentary lifestyle, low water intake or dietary practices insufficient in fiber intake $[62,63]$. These patients rarely seek help from health professionals for the treatment of constipation, they lack the initiative to change their lifestyles, and they have unhealthy habits, resulting in negative consequences for their quality of life and health [64] that contribute to the clinical treatment failure of MPS.

Althouth we observed several important results in this study, it is important to highlight that some limitations of the study may be associated with the shortcomings of the tools we used to evaluate pain intensity and fiber intake. Visual Analog Scale is a validated, easy-to-use, and rapid scale to estimate pain intensity [65]. However, it is a one-dimensional instrument used to identify pain on the day of evaluation and therefore limited to assessing only the pain intensity, disregarding the important aspect of impact of pain on the patient's well-being [66]. To minimize this limitation, pain intensity was assessed by a specialist in pain treatment who has been trained in VAS application.

Similarly, to assess fiber intake, we used the 24-hour recall because it has been widely used in food consumption studies $[67,68]$. The low correlation between measurement errors in nutrient estimates (especially carbohydrates, 
lipids, fiber, and energy) explains the preference for 24-hour recall over other methods. However, the instrument depends on the patient's memory and may present evaluation errors if an atypical food pattern is used as reference. To minimize potential observation errors, the researchers performed the evaluation on two random week days, excluding weekends. If an individual reported an atypical food pattern, a new appointment was scheduled in the same week. We also emphasize here that the researchers who preformed the evaluation were different than the ones involved in statistical analyses.

Thus, further studies of a clinical and epidemiological nature should be performed to identify changes in constipation in subjects with MPS. We also suggest performing new research studies to identify the efficacy of therapeutic maneuvers that can improve intestinal motility and to assess their effects on the clinical progression of pain.

\section{CONCLUSION}

Constipation was a frequent nosological entity in patient with Myofascial Pain Syndrome. In this patients, the persistence of a change in intestinal motility disorders showed a significant correlation with the pain intensity and low water intake. The inadequate water intake and use of benzodiazepines could be associated with the reduction in the number of defecations per week in this poputation. Notably, maintaining a normal intestinal rhythm can support chronic pain treatment in these patients, whereas neglecting its existence most likely

\section{CONTRIBUTORS}

All authors contributes to treatment failure.

\section{RE FERE N CES}

1. Brioschi EFC, Brioschi ML, Yeng LT, Teixeira MJ. Nutrição funcional no paciente com dor crônica. Rev Dor. 2009;10(3):276-85.
2. Gerwin RD. Myofascial trigger point pain syndromes. Semin Neurol. 2016;36(5):469-73.

3. Travell J, Simons D, Simons L. Travell \& Simons myofascial pain and dysfunction: The trigger manual. 2nd ed. Baltimore: Williams \& Wilkins; 1999. v. 1

4. Simons DG. New views of myofascial trigger points: Etiology and diagnosis. Arch Phys Med Rehabil. 2008;89(1):157-9. https://doi.org/10. 10 16/j.apmr.2007.11.016

5. Gerwin RD. Diagnosis of myofascial pain Syndrome. Phys Med Rehabil Clin N Am. 2014;25(2):341-55. https://doi.org/10.1016/j.pmr.2014.01.011

6. Bron C, Franssen J, Wensing M, Oostendorp RAB. Interrater reliability of palpation of myofascial trigger points in three shoulder muscles. J Man Manip Ther. 2007;15(4):203-15. https://doi.org/10. 1179/106698107790819477

7. Barbero M, Bertoli P, Cescon C, MacMillan F, Coutts F, Gatti R. Intra-rater reliability of an experienced physiotherapist in locating myofascial trigger points in upper trapezius muscle. J Man Manip Ther. 2012;20(4):171-7. https://doi.org/10. 1179/2042618612Y.0000000010

8. Gamero RF, Gabriel SR, Carbonell AJ, Tornero MJ, Sánchez-Magro I. Pain in Spanish rheumatology outpatient offices: EPIDOR epidemiological study. Rev Clin Esp. 2005;205(4):157-63. https://doi. org/10.1157/13074161

9. Gerwin RD. A study of 96 subjects examined both for fibromyalgia and myofascial pain. J Musculoske Pain. 1995;3(Suppl.1):121.

10. Borg-Stein J, Laccarino MA. Myofascial pain syndrome Treatments. Phys Med Rehabil Clin N Am. 2014;25(2):357-74. https://doi.org/10.1016/j. pmr.2014.01.012

11. Helfestein $M J r$, Heymann $R$, Feldman $D$. Prevalência de Síndrome do cólon Irritável em pacientes com fibromialgia. Rev Bras Reumatol. 2006;46(1):16-23. https://doi.org/10.1590/S0482-50 042006000100005

12. Cole JA, Rothman KJ, Cabral HJ, Zhang Y, Farraye FA. Migraine, fibromyalgia, and depression among people with IBS: A prevalence study. BMC Gastroenterol. 2006;6(26). https://doi.org/10.11 86/1471-230X-6-26

13. Rao SSC. Constipation: Evaluation and treatment of colonic and anorectal motility disorders. Gastroenterol Clin N Am. 2007;36(3):687-711. https://doi.org/10.1016/j.gtc.2007.07.013

14. Schmulson M, Lee OY, Chang L, Naliboff B, Mayer EA. Symptom differences in moderate to severe IBS patients based on predominant bowel habit. Am J 
Gastroenterol. 1999;94(10):2929-35. https://doi. org/10.1111/j.1572-0241.1999.01440.x

15. Rusu F, Dumitra cu DL. Four years follow-up of patients with irritable bowel syndrome. Rom J Intern Med. 2015;53(1):63-72. https://doi.org/10. 1515/rjim-2015-0009

16. Pezzone MA, Liang $R$, Fraser MO. A model of neural cross-talk and irritation in the pelvis: Implications for the overlap of chronic pelvic pain disorders. Gastroenterology. 2005;128(7):1953-64. https://doi.org/10.1053/j.gastro.2005.03.008

17. Christianson JA, Liang R, Ustinova EE, Davis BM, Fraser MO, Pezzone MA. Convergence of bladder and colon sensory innervation occurs at the primary afferent level. Pain. 2007;128(3):235-43. https://doi.org/10.1016/j.pain.2006.09.023

18. Malykhina AP. Neural mechanisms of pelvic organ cross-sensitization. Neuroscience. 2007;149(3):660-72. https://doi.org/10.1016/j. neuroscience.2007.07.053

19. Butrick CW. Interstitial cystitis and chronic pelvic pain: New insights in neuropathology, diagnosis, and treatment. Clin Obstet Gynecol. 2003;46(4):811-23.

20. Borkathur A, Saksena S, Gill RK, Alrefai WA, Ramaswamy K, Dudeja PK. Regulation of monocarboxylate transporter 1 (MCT1) promoter by butyrate in human intestinal epithelial cells: Involvement of NF-kappaB pathway. J Cell Biochem. 2008;103(5):1452-63. https://doi.org/10. 1002/jcb.21532

21. Barros-Neto JA, Machado AS, Kraychete DC, Jesus RP. Comprometimento da integridade intestinal na fibromialgia e sindrome dolorosa miofascial: uma revisão. Rev Ciênc Med Biol. 2011;10(3):246-53.

22. Hatakeyama N, Matsuda N. Alert cell strategy: Mechanisms of inflammatory response and organ protection. Curr Pharm Des. 2014;20(36)5766-78.

23. Swieboda P, Filip R, Prystupa A, Drozd $M$. Assessment of pain: Types, mechanism and treatment. Ann Agric Environ Med. 2013;1:2-7.

24. Tick H. Nutrition and pain. Phys Med Rehabil Clin N Am. 2015;26(2):309-20.

25. National Pain Management Coordinating Committee, Veterans Health Administration. Pain as the 5th vital sign toolkit, revised edition. Washington (DC): National Pain Management Coordinating Committee, Veterans Health Administration; 2000.

26. Ford ES, Kohl HW, Mokdad AH, Ajani UA. Sedentary behavior, physical activity, and the metabolic syndrome among U.S. adults. Obes Res. 2005;13(3):608-14.
27. Haskell WL, Lee IM, Pate RR, Powell KE, Blair SN, Franklin BA, et al. A Physical activity and public health: Updated recommendation for adults from the American College of Sports Medicine and the American Heart Association. Med Sci Sports Exerc. 2007;39(8):1423-34. https://doi.org/10.1249/mss. Ob013e3180616b27

28. Institute of Medicine. Dietary Reference Intakes for energy, carbohydrate, fiber, fat, fatty acids, cholesterol, protein and amino acids. Washington (DC): National Academies Press; 2005.

29. Fundação Instituto Brasileiro de Geografia e Estatística. Tabela de composição de alimentos. $2^{\mathrm{a}}$ ed. Rio de Janeiro: IBGE; 1985.

30. Institute of Medicine. Dietary Reference Intakes for water, potassium, sodium, chloride and sulfate. Washington (DC): National Academies Press; 2004.

31. Lohman TG, Roche AF, Martorell R. Anthropometric standardization references manual. Champaign (III): Human Kinetics; 1988.

32. Lohman TG. Advances in body composition assessment. Champaign (III): Human Kinetics Publishers; 1992.

33. World Health Organization. Physical status: The Use and Interpretation of anthropometry. Report of a WHO Expert Committee. Technical Report Series, n 854. Geneva: WHO; 1995.

34. Longstreth GF, Thompson WG, Chey WD, Houghtom LA, Mearin F, Spiller RC. ROMA III: Functional bowel disorders. Gastroenterology. 2006;130(5):1480-91. https://doi.org/10.1053/j. gastro.2005.11.061

35. Maciel ACC, Fernandes MB, Medeiros LS. Prevalência e fatores associados à sintomatologia dolorosa entre profissionais da indústria têxtil. Rev Bras Epidem. 2006;9(1):94-102. https://doi. org/10.1590/S1415-790X2006000100012

36. Coury HJCG, Moreira RFC, Dias NB. Efetividade do exercício físico em ambiente ocupacional para controle da dor cervical, lombar e do ombro: uma revisão sistemática. Rev Bras Fisioter. 2009;13(6):461-79. https://doi.org/10.1590/S141 3-35552009000600002

37. Walling K, Sundelin G, Ahlgren C, Järvholm B. Perceived pain before and after there exercise programs: A controlled clinical trial of women with work-related trapezius myalgia. Pain. 2000;85(1-2):201-7.

38. Kurland JE, CoyleWJ, Winkler A, ZableE. Prevalence of irritable bowel syndrome and depression in fibromyalgia. Dig Dis Sci. 2006;51(3):454-60. https://doi.org/10.1007/s10620-006-3154-7 
39. Naliboff BD, Derbyshire SW, Munakata J, Berman S, Mandelkern M, Chang L, et al. Cerebral activation in patients with irritable bowel syndrome and control subjects during rectosigmoid stimulation. Psychosom Med. 2001;63(3):365-75.

40. Lychkova AE. Role of serotonin in systemic impairment of motor function of the digestive tract. Bull Experim Biol Med. 2009;147(4):444-7.

41. Wei F, Dubner R, Zou S, Ren K, Bai G, Wei $D$, et al. Molecular depletion of descending serotonin unmasks its novel facilitatory role in the development of persistent pain. J Neurosci. 2010;30(25):8624-36. https://doi.org/10.1523/ JNEUROSCI.5389-09.2010

42. Tack J, Sarnelli G. Serotonergic modulation of visceral sensation: Upper gastrointestinal tract. Gut. 2002;51(Suppl.1):i77-i80. https://doi.org/10. 1136/gut.51.suppl_1.i77

43. Atkinson W, Lockharts S, Whorwell PJ, Keevil B, Houghton LA. Altered 5-hydroxytryptamine signaling in patients with constipation- and diarrhea-predominant irritable bowel syndrome. Gastroenterology. 2006;130(1):34-43. https://doi. org/10.1053/j.gastro.2005.09.031

44. Brumovsky P, Shi TS, Landry M, Villar MJ, Hokfelt T. Neuropeptide tyrosine and pain. Trends Pharmacol Sci. 2007;28(2):93-102. https://doi.org/10.1016/j. tips.2006.12.003

45. Foreman RD. Neurological mechanisms of chest pain and cardiac disease. Cleve Clin J Med. 2007;74(Suppl.1):S30-S3.

46. Chaban V, Christensen A, Wakamatsu M, McDonald M, Rapkin A, McDonald J, et al. The same dorsal root ganglion neurons innervate uterus and colon in the rat. Neuroreport. 2007;18(3):209-12. https://doi.org/10.1097MNR. Ob013e32801231bf

47. Brederson JD, Jarvis MF. Homomeric and heteromeric $\mathrm{P} 2 \mathrm{X} 3$ receptors in peripheral sensory neurons. Curr Opin Investig Drugs. 2008;9(7):716-25.

48. Broad LM, Mogg AJ, Beattie RE, Ogden AM, Blanco MJ, Bleakman D. TRP channels as emerging targets for pain therapeutics. Expert Opin Ther Targets. 2009;13(1):69-81. https://doi. org/10.1517/14728220802616620

49. Qin C, Malykhina AP, Akbarali HI, Foreman RD. Cross-organ sensitization of lumbosacral spinal neurons receiving urinary bladder input in rats with inflamed colon. Gastroenterology. 2005;129(6):1967-78. https://doi.org/10.1053/j. gastro.2005.09.013

50. Cory L, Harvie HS, Northington G, Malykhina A, Whitmore K, Arya L. Clinical evidence of a neurogenic mechanism for the co-existence of urinary and bowel symptoms in women with bladder pain syndrome. J Urol. 2012;187(2):503-7. https://doi.org/10.1016/j.juro.2011.10.036

51. Liebregts T, Adam B, Bredack C, Röth A, Heinzel $S$, Lester $S$, et al. Immune activation in patients with irritable bowel syndrome. Gastroenterology. 2007;132(3):913-20. https://doi.org/10.1053/j. gastro. 2007.01.046

52. Barkhordari E, Rezaei N, Ansaripour B, Larki P, Alighardashi M, Ahmadi-Ashtiani HR, et al. Proinflammatory cytokine gene polymorphisms in Irritable Bowel Syndrome. J Clin Immunology. 2010;30(1):74-9. https://doi.org/10.1007/s10875-0 09-9342-4

53. Verri WJ, Cunha T, Parada C, Poole S, Cunha FQ, Ferreira SH. Hypernociceptive role of cytokines and chemokines: targets for analgesic drug development?. Pharmacol Ther. 2006;112(1):116-38. https://doi.org/10.1016/j. pharmthera.2006.04. 001

54. Panis C, Pavanelli WR. Cytokines as mediators of pain-related process in breast cancer. Mediators Inflamm. 2015; 2015:129034. https://doi.org/10. $1155 / 2015 / 129034$

55. U.S. Departments of Agriculture and Health and Human Services. Dietary Guidelines for Americans, 2010. 7th ed. Washington (DC): US Government Printing Office; 2010.

56. Beaton GH. Approaches to analysis of dietary data: Relationship between planned analyses and choice of metodology. Am J Clin Nutr. 1994;59(Suppl.1):253-61.

57. Schmier JK, Miller PE, Levine JA, Perez V, Maki $K C$, Rains TM, et al. Cost savings of reduced constipation rates attributed to increased dietary fiber intakes: A decision-analytic model. BMC Public Health. 2014;14:374. https://doi.org/10. 1186/1471-2458-14-374

58. Christodoulides S, Dimidi E, Fragkos KC, Farmer AD, Whelan K, Scott SM. Systematic review with meta-analysis: Effect of fibre supplementation on chronic idiopathic constipation in adults. Aliment Pharmacol Ther. 2016;44:103-16. https://doi.org/10. 1111/apt.13662

59. Popkin BM, D'Anci KE, Rosenberg IH. Water, hydration and health. Nutr Rev. 2010;68(8):439-58. https://doi.org/10.1111/j.1753-4887.2010.003 04.x

60. Ho KS, Tan CYM, Daud MAM, Seow-Choen F. Stopping or reducing dietary fiber intake reduces constipation and its associated symptoms. World J Gastroenterol. 2012;18(33):4593-6. https://doi. org/10.3748/wjg.v18.i33.4593 
61. De Hert M, Hudyana H, Dockx L, Bernagie C, Sweers K, Tack J, et al. Second generation antipsychotics and constipation: A review of the literature. Eur Psychiatr. 2011;26(1):34-44. https:// doi.org/10.1016/j.eurpsy.2010.03.003

62. Raepsaet J, Knapen J, Vancampfort D, Probst M. Motivation to physical activity in non-psychotic psychiatric inpatients. Int J Psychosoc Rehabil. 2010;15(11):51-60.

63. Wong WK, Chien WT, Lee WM. Self-administered acupressure for treating adult psychiatric patients with constipation: A randomized controlled trial. Chin Med. 2015,3:10-32. https://doi.org/10.11 86/s13020-015-0064-7

64. De Hert M, Dockx L, Bernagie C, Peuskens B, Sweers K, Lecht S, et al. Prevalence and severity of antipsychotic-related constipation in patients with schizophrenia: A retrospective descriptive study. BMC Gastroenterol. 2011;11(17):1-4. https://doi. org/10.1186/1471-230X-11-17

65. Farrar JT, Pritchett YI, Prakash A, Chappell A. The clinical importance of changes in the 0 to 10 Numeric Rating Scale for worst, least and average pain intensity: Analyses of data from clinical trials of duloxetine in pain disorders. J Pain. 2010;11:109-18. https://doi.org/10.1016/j. jpain.2009.06.007

66. Martinez JE, Grassi DC, Marques LG. Análise da aplicabilidade de três instrumentos de avaliação de dor em distintas unidades de atendimento: ambulatório, enfermaria e urgência. Rev Bras Reumatol. 2011;51(4):304-8. https://doi.org/10. 1590/S0482-50042011000400002

67. Buzzard M. 24-hours dietary recall and food record methods. In: Willett WC. Nutritional epidemiology. 2nd ed. New York: Oxford University Press; 1998. p.50-73.

68. Costa AGV, Priore SE, Sabarense CM, Franceschini SCC. Questionário de frequência de consumo alimentar e recordatório de 24 horas: aspectos metodológicos para avaliação da ingestão de lipídeos. Rev Nutr. 2006;19(5):631-41. https://doi. org/10.1590/S1415-52732006000500011

Received: September 30, 2016

Final version: May 2, 2017

Approved: May 16, 2017 
